\title{
A Review Study on Fluoride Toxicity in Water and Fishes: Current Status, Toxicology and Remedial Measures
}

\author{
Rajinder Kaur, Amita Saxena, Munish Batra* \\ Department of Fisheries Resource Management, College of Fisheries, GBPUA\&T, Pantnagar, India \\ *Department of Veterinary Pathology, College of Veterinary and Animal Sciences, G. B. Pant University of Agriculture \& \\ Technology, Pantnagar, Uttarakhand, India
}

\begin{abstract}
Fluoride is widely distributed in nature in many forms and its associated compounds have been used extensively but its limit in water is exceeding the permissible level. Excess of fluoride (>1.5 $\mathrm{mg} / \mathrm{l})$ in drinking water is harmful to the health. Fluoride toxicity is increasingly becoming a matter of great concern as many countries in the world have been declared as endemic for fluoride. This makes it imperative for scientists to focus on the precise toxic effects of fluoride on various soft tissues. Fluoride is toxic to all the system and causes oxidative stress in various tissues. When fluoride is ingested, approximately $93 \%$ is absorbed into the bloodstream. Contamination of drinking water due to fluoride is a severe health hazard problem. A good part of the material is excreted but the rest is deposited in the bones and teeth and is capable of causing a crippling skeletal fluorosis, non-skeletal fluorosis and dental fluorosis. There are various treatment technologies for removing fluoride from groundwater but these methods are very expensive. Besides using the water treatment techniques, various plants are having therapeutic properties to reduce the fluoride toxicity which is a cost effective to cure the fluoride induced toxicity.
\end{abstract}

Keywords- Fluoride, Water, Fluorosis, Fishes, Defluoridation, Medicinal plants.

\section{INTRODUCTION}

Water is the most abundant and essential life supporting component. But now days, most of the countries in the world are facing the problem of drinking water. In India, drinking water is found to be contaminated at many places by different kinds of pollutants such as fluorides, iron and nitrates etc. Pure water is scarce and not easily available to all living beings including human being, birds, animals as well as plants. Deprived sections of the society consume contaminated water and become sick periodically, often results in the outbreak of epidemics. The water may be contaminated by natural sources or by the industrial effluents. One such contaminant is fluoride.
The fluorides belong to the halogen group of minerals and are natural constituents of the environment. Fluoride is an essential element for life which is mainly found in ground water when it is derived by the solvent action of water on the rocks and the soil of the earth's crust. It is the most electronegative of all chemical elements and is never encountered in nature in the form of element. It is seventeenth in the order of frequency of occurrence of the elements and represents about $0.06 \%$ to $0.09 \%$ of the earth's crust (Wedepohl, 1974). World Health Organization (WHO) and IS: 10500 recommended that the permissible limit of fluoride content in drinking water is 1.0 to1.5 ppm. At low concentration, fluoride deficiency can occur but at high concentrations of fluoride some deleterious effects can arise. In relation to drinking water it is generally believed that too little $(<0.5 \mathrm{mg} / \mathrm{l})$ or too high $(>1.5 \mathrm{mg} / \mathrm{l})$ can affect bone and teeth structure (Edmunds and Smedley, 1996 and 2003). Among the water quality parameters, fluoride ion exhibits unique properties as its optimum concentration in drinking water is advantageous to health and in case of exceeding concentration above the permissible limit affects the health (Venkata et al., 1995). High fluoride concentration in the ground water and surface water in many parts of the world is of great concern. The main source of fluoride in ground water is fluoride-bearing rocks such as cryolite, fluorite, fluorspar, fluorapatite and hydroxylapatite (Meenakshi et al., 2004). The content in ground water is a function of many factors such as solubility and availability of fluoride minerals, $\mathrm{pH}$, temperature and velocity of flowing water and concentration of calcium and bicarbonate ions in water. (Agarwal et al., 1977; Chandra et al., 1981). Fluoride enters the body through water, drugs, food, industrial exposure, etc. but among the other souces, drinking water is the major source $(75 \%)$ of daily intake. Because of the strong electronegative charge, fluoride is attracted towards the positively charged calcium in teeth and bones. It causes many health problems such as dental fluorosis, skeletal fluorosis, teeth 
mottling and deformation of bones in human beings (Susheela et al., 1993). Excessive fluoride concentration affects both plants and animals. It is oftenly considered as a "two edged sword" because deficiency of fluoride intake leads to dental caries while excessive consumption leads to dental and skeletal fluorosis. So the fluoride is harmful in both the cases i.e., deficiency and excess. Kharb and Susheela (1994) reported that fluoride has also affected the soft tissues such as muscles and ligaments. Fluorosis is an important clinical and public health problem in several parts of the world. Global existence of fluorosis is reported to be about $32 \%$ (Varier, 1996).

The conventional method of defluorination includes: adsorption, ion-exchange and reverse osmosis (Amor $\boldsymbol{e t}$ al., 1998; Hichour et al., 1999, 2000). The ion-exchange and reverse osmosis process are relatively expensive than adsorption. Therefore, still adsorption is considered to be the most viable method to defluoridate the water. In this process, contaminated water is passed through an adsorbent bed, where fluoride can be removed by ionexchange, physical or surface chemical reaction with adsorbent. As this method is easy to operate and costeffective, adsorption is still widely accepted as an efficient pollution removal technique. Various publications are available on effective fluoride removal methods using low cost materials. Several tested materials include activated carbon, activated alumina, amorphous alumina, bleaching earth, calcite, charcoal, zeolite clay and red mud etc (Rubel, 1983; Yang et al., 1999; Li et al., 2001; Wang and Reardon, 2001; Christopher et al., 2004). The materials like bentonite, lignite, charfines, kaolinite, and nirmali seeds were also investigated for the removal of fluoride (Srimurali et al., 1998). Plant materials are also reported to accumulate fluoride and hence act as defluoridating agents and also Vitamin $\mathrm{C}$ is an efficient source to reduce fluoride.

\section{PERMISSIBLE LIMITS FOR FLUORIDE CONCENTRATION IN DRINKING WATER (VARADAJAN AND PURANDARA, 2008)}

- Bureau of Indian Standards (BIS)-0.6 to $1.2 \mathrm{mg} / \mathrm{l}$

- World health Organization (WHO-1984) for drinking water-1 to $1.5 \mathrm{mg} / \mathrm{l}$

- Indian Council of Medical Research (ICMR1975)-1 mg/l

- World Health Organization (WHO) European Standards- 0.7 to $1.7 \mathrm{mg} / \mathrm{l}$ related to temperature.

\section{SCENARIO OF FLUOROSIS AT GLOBAL LEVEL}

Fluoride content is high in various parts of the world and it causes adverse effects to the living beings. Fluorosis is a health problem of global community as 23 nations across the world are facing this problem (Basha et al., 2010). Especially, it is prevalent in the third- world countries where most of the people are dependent on drinking water containing fluoride (Madhusudhan et al., 2009). The problem of dental fluorosis is a major issue in many countries like China, India and Mexico (Pendrys and Katz, 2001). Apart from these nations, Argentina, Algeria, Egypt, Iran, Australia, Iraq, Japan, Jordan, Kenya, Libya, Morocco, New Zealand, Pakistan, South Africa, Syria, Tanzania, Thailand, Turkey and United States of America are under the threat of fluorosis. Approximately $6 \%$ of the total population of Mexico is affected by fluorosis (Valdez et al., 2011). The epidemiological studies that have been conducted in China have shown that about 330 million people are exposed to high fluoride content and among them about 42 million people are suffering from fluorosis (Wang $\boldsymbol{e t}$ al., 2004). High fluoride concentrations in groundwater are found in the Africa, Australia, China, Ghana, India, Kenya, Sri Lanka, Tanzania and USA besides other countries in different continents (Jagtap et al., 2012).

\section{FLUORIDE LEVEL IN INDIAN WATER}

Fluoride content is above the permissible levels of $1.5 \mathrm{ppm}$ occur in 14 Indian states, namely, Andhra Pradesh, Bihar, Rajasthan, Gujarat, Haryana, Karnataka, Uttar Pradesh, Kerala, Madhya Pradesh, Maharashtra, Orissa, Punjab, Tamil Nadu and West Bengal affecting about 69 districts. It has been found that 65 per cent of India's villages are at fluoride risk (Kumar and Shah, 2006).

In India, about 25 million people are affected by fluorosis, especially in the states of Andhra Pradesh, Bihar, Delhi, Gujarat, Haryana, Jammu Kashmir, Kerala, Madhya Pradesh, Maharashtra, Punjab, Rajasthan and Tamil Nadu. In India, about 66.62 million people are at the risk of fluorosis (Susheela, 2007). According to the recent survey by International Water Management Institute (IWMI) in north Gujarat, the results showed that 42 per cent of the people covered in the sample survey $(28,425)$ were affected; while 25.7 per cent and 6.2 per cent were affected by dental fluorosis and muscular skeletal fluorosis respectively. 10 per cent were affected by both the types of fluorosis.

\section{GENERAL MECHANISM OF TOXICITY}

A review by Barbier et al. (2010) has sketched a number of cellular processes in which fluoride can have negative effects. Effects that have been identified through different experimental studies include alteration of gene 
expression, disruption of enzyme activity (mostly inhibition), inhibition of protein synthesis and secretion and generation of reactive oxygen species (ROS).

Fluoride disrupts the activity of enzyme by binding it to the functional amino acid groups that encircles the enzyme's active centre. This consists of the enzyme inhibition of the glycolytic pathway and the Krebs cycle (Barbier et al., 2010). At micromolar and millimolar concentrations, fluoride can act as an anabolic agent and promote the cell proliferation and an enzyme inhibitor respectively. This is illustrated from the study of Mendoza-Shulz et al. (2009). There is an example of phosphatases, which play an important role in the ATP (cellular energy) production cycle and cellular respiration. Fluoride interrupts the signalling pathways which are involved in cell proliferation and apoptosis and then cause the inhibition of protein synthesis and secretion (Barbier et al., 2010). It has been found that fluoride has association with oxidative stress which can lead to the reduction of mitochondrial fitness and also degrades the cellular membranes. The increase of oxidative stress leads to an increase in the expression of genes responsible for stress response (Barbier et al., 2010).

\section{TOXICOLOGICAL EFFECTS OF FLUORIDE ON FISH}

Fluoride is present in the environment as the stable form of the super reactive element fluorine. Fluorine is the seventeenth most plentiful element in the earth's crust, with fluoride detectable in almost all minerals. The main minerals are Cryolite $\left(\mathrm{Na}_{3} \mathrm{AlF}_{6}\right)$, Fluorspar $\left(\mathrm{CaF}_{2}\right)$ and Fluorapatite $\left(\mathrm{Ca}_{10} \mathrm{~F}_{2}\left(\mathrm{PO}_{4}\right)_{6}\right)$. Naturally, through the weathering of alkalic and silicic igneous and sedimentary rocks, primarily shales, as well as from emissions of volcanic eruption, fluoride enters the aquatic system. It has been found that in freshwater there is a concentration less than $1.0 \mathrm{mg} / \mathrm{l}$ and in natural water, its concentrations may exceed even 50.0mg/l (McNeely et al., 1979). To judge on the potential environmental impacts of fluoride, it is important to firstly gather the current available information about its impact on the homeostasis within organisms. However, the evidences from the studies conducted till now are not conclusive whether fluoride is essential for any other biological function or not (Government of British Columbia, 1990). The most common disorder associated with the excessive fluoride level is fluorosis. This condition is related to the retention of excess fluoride content within the body and its harmful integration into biochemical pathways, often as a replacement for calcium (Barbier et al., 2010).

\subsection{Effect on behaviour}

Behavioural alterations can be considered as sensitive indicators of environmental stress. Many studies have been done to observe the behavioural changes in aquatic organisms due to exposure of pollutants (Shaikh, 1999). Fluoride induced changes in the behaviour of fresh water fishes have been reported from different experiments (Aziz et al., 2014). Delay in trout migration has been reported by Neuhold and Sigler (1960) at measurable level of fluoride. Manna et al., 2007 observed the adverse effect due to fluoride toxicity includes enzyme inhibition, collagen breaks down, gastric damage and disruption of the immune system. Bajpai et al., (2009) have also reported the behavioural abnormalities on the exposure of sodium fluoride to the experimental fishes include erratic swimming, fast breathing, loss of schooling behaviour and secretion of large amount of mucus on body of Heteropneustis fossilis. Narwaria and Saksena (2012) reported that the behavioural responses due to sodium fluoride toxicity include body position, habit, food sensitivity, rate of operculum opening and swimming movements. However the accumulation and increased mucus secretion in the fluoride exposed fish may be an adaptive and protective response to avoid the absorption of the applied toxicant by the overall body surface (Das and Mukherjee, 2003; Yilmaz et al., 2004). Due to fluoridicated toothpaste, changes in the behaviour of Clarias batrachus and Catla catla were reported by Sahu et al. (2014) and Verma et al. (2015) respectively. The behavioural changes in feeding, swimming movement, body orientation, opercular activity, gulping activity, mucus secretion and body coloration were observed.

\subsection{Effect on growth and development}

During the study of growth parameters, physical variables are taken into consideration such as length, weight, volume etc. Exposures to trace elements and fluoride affect the developmental stages of aquatic organism (Thurberg et al., 1975). Ellis et al., (1948) reported delay in hatching time when the fish eggs were subjected to 1.5ppm fluoride level. Shi et al., (2009 a, b) have reported the significant increase in fluoride concentration in bone, gill, cartilage and skin of Siberian sturgeon when exposed to lethal dose of fluoride. Tripathi et al. (2005) found that the higher concentrations of Fluoride inhibit the growth of fishes such as weight, length and of fingerlings of Heteropneustis fossilis. According to Bajpai and Tripathi (2010) lipid and protein act as growth bioindicator against fluoride pollutant in Heteropneustis fossilis. These biomolecules gets reduced in the body tissues after the chronic exposure of fluoride. Hence, resulted in the depletion of the appropriate growth and development of fish. Agniwanshi et al., (2014) studied the effect of sodium fluoride on body weight gain and gonadosomatic index in freshwater catfishes and revealed a statistically significant effect of different doses of sodium fluoride on gonadosomatic index (GSI) and 
body weight gain in both species, i.e., Clarias batrachus and Heteropneustes fossilis which is irrespective of phase of annual reproductive cycle. It has also been noticed the concentration of sodium fluoride is having inverse relationship with the body weight as the increase in the fluoride content results in decrease in body weight gain. Further, in both the sexes i.e., male and female of Clarias batrachus and Heteropneustes fossilis GSI were found to decrease in most of the groups maintained in different concentrations of sodium fluoride as compared to control group.

\subsection{Effect on Chromatophores}

The various studies have been conducted indicating the negative effect of pollutants in fishes but very little information is available about their effect on pigmentation. Chromatophores are reponsible for the change of colour in fishes at the time of courtship, protection, mating and reproduction (Fujii, 2000). The study on effect of fluoride on coloration in Heteropneustis fossilis and Channa punctatus respectively found that continuous exposure of sodium fluoride resulted in altered size, shape and dispersion quality of chromatephores in the skin of Heteropneustis fossilis. Chromatophore numbers were increased while their size was reduced and shape of chromatophores become stellate in comparisons to reticulate chromatophore of control group (Tripathi $\boldsymbol{e t}$ al., 2005; Bajpai et al., 2012).

\subsection{Effect on Reproductive System}

Fluoride adversely affects the structure and mobility of sperm causes alteration in the level of reproductive hormones. Shingadia and Agharia (2001) observed histoarchitectural changes in the testis and ovary of larvivorous fish because of fluoride exposure. In testis, it caused degeneration of seminiferous tubules and their epithelium due to denudation and vacuolization of cells, atrophy of spermatocyte and hyperplasia of sertoli cells where as in ovary, it caused hyperplasia of germinal epithelial and involution of ova, decreased frequency of oocyte maturatin and cytoplasmic vaculolation. Kasirsagar et al (2011) reported damaged oocyte, disorganization of ooplasm, inhibition of ovarian development and empty space of follicle in fresh water fish Rita rita due to the fluoride induced toxicity.

\subsection{Effect on Haematology}

Saxena et al. (2001) reported significant decrease in TEC, $\mathrm{Hb}, \mathrm{PCV}, \mathrm{MCV}, \mathrm{MCH}$ and $\mathrm{MCHC}$ with increase in the concentration of fluoride in Channa punctatus. Gupta et al. (2002) also found that fluoride caused decrease in TEC, Hb, PCV, ESR while TLC was increased in Channa punctatus and Labeo rohita. Kumar et al., (2007) reported significant decrease in the content of $\mathrm{RBC}, \mathrm{Hb}$, PCV and carrying capacity of oxygen by blood in Clarias batrachus. Time and dose dependent decrease in RBC, WBC count and Hb was observed by Kamble and Velhal (2010) at different concentrations of fluoride i.e., $100 \mathrm{ppm}, 200 \mathrm{pm}$ and $300 \mathrm{ppm}$. The results indicated immunological suppression. Study on fluoride toxicity in Clarias batrachus by Guru et al., 2014 has shown clumping of RBCs and clumping becomes prominent at higher fluoride concentrations. The TEC, $\mathrm{Hb}, \mathrm{PCV}$, $\mathrm{MCV}, \mathrm{MCH}$ and MCHC level was progressively decreased with an increase in the concentration of fluoride.

\subsection{Effect on serum and tissue biomolecules}

Studies by Chitra et al., 1983 and Kumar et al., 2007 have shown that fluoride affects the certain biomolecules and enzymes in different tissue of fresh water fishes. Fluoride mainly affects the cholesterol, glucose, protein, lipid and glycogen level as all these biomolecules play a pivotal role in survival, growth and reproduction of fishes. Dousset et al., (1987) and Gikunju et. al. (1992) have reported an increase in the cholesterol level in liver, muscle and testis of fishes due to fluoride doze. Alteration in the level of these biomolecules can results in reduction of fish growth and population. Calcium (Ca) and magnesium $(\mathrm{Mg})$ act as second messenger for replication, transcription and translation. Fluoride reduces the absorption of both $\mathrm{Ca}$ and $\mathrm{Mg}$ from fish gut (Machoy, 1995). Kumar et al., 2007 conducted an experiment to study the fluoride-induced biochemical changes in different tissues such as muscle, liver, and testis of fresh water catfish. There was significant decrease in the glycogen content in muscle and testis at the lower concentration but at the same time it was increased in all the three tissues at the higher concentration. Aziz et al., 2013 have found that fluoride increased the alkaline phosphatase (ALP), alanine aminotransferase (ALT), aspartate aminotransferase (AST) level in gills of fresh water fish Oreochromis mossambicus. The exposure of sodium fluoride $(\mathrm{NaF})$ to the larvivorous fish (Poecilia reticulate) revealed stress on respiratory metabolism and led to decrease in Succinic dehydrogenase and Lactate dehydrogenase (LDH) enzymes which are involved in carbohydrate metabolism and this decrease might have led to metabolic shift from aerobic to anaerobic mode of respiration during the toxic phase of fluoride induced stress (Shingadia and Agharia, 2013).

\subsection{Genotoxicity and Cytotoxicity in fish}

It has been reported that on exposure to high content of fluoride, it inhibits the cell proliferation, growth and induced apoptosis. Jha (2004) has seen DNA and cytogenetic alterations in aquatic organisms impaired enzyme function or general metabolism, abnormal 
development, immunotoxicity, cytotoxicity, reduced growth, survival and reproduction potency. According to some reports, fluoride caused chromosomal aberration and DNA damage in mammalian cells. (Joseph et al., 2000; Podder et al., 2008). Tripathi et al. (2009) reported that the chromosomal aberrations increased with the increase in fluoride dose in Clarias batrachus. Results of the research experiments have shown that fluoride influences the different singling pathways which are involved in cell proliferation and apoptosis (Barbier $\boldsymbol{e t}$ al., 2010). Cytotoxic and genotoxic studies in fish are demonstrating the sensitivity of these organisms. Micronuclei test (MNT), Comet assay and Chromosomal aberration test (CAT) are the most commonly and widely used methods to prove genotoxicity in fish (Garg and Sharma, 2012).

\subsection{Effect on Histology}

Tripathi et al. (2006) reported the effect of fluoride on vertebral coloumn of Channa punctatus and its results revealed that fluoride caused decrease in diameter of neural canal and increase of bone density. Bhatnagar $\boldsymbol{e t}$ al., 2007 visualized the fluoride-induced histopathological changes in gill, intestine and kidney of fresh water fish, Labeo rohita. In the fluoride exposed group, with increasing severity with the time, the gill tissue developed clubbed lamellae, lamellar hyperplasia and mucoid metaplasiad. The kidney showed renal architectural damage in the form of shrunken glomeruli, shrunken lumen of renal tubules, increased capsular space and vacuolated cytoplasm. The intestine exhibited flattening and fusion of villi and a cracked clay appearance. All these changes were not seen in the control group.

Haque et al., 2012 observed severe vacuolation in the gastric epithelium and disruption in the tubular gastric glands of the stomach occurred. In the stomach, there was loss of microridges with vigorous mucus secretion, degeneration of epithelial cells and disarrangement of mucosal folds. Changes in the intestine include degeneration of villi with severe necrosis in absorptive columnar epithelial cells and also the fusion of cells at the basal region was visible. The disruption of primary and secondary mucosal folds resulted in reducing the absorptive luminal surface area. The centrolobular area of the liver exhibited focal necrosis. The zymogen granules gets scattered in the hepatopancreatic acinar cells and these changes resulted into the cell's degranulation and vacuolation. Kidney showed disruption of Bowman's capsule and degradation in the epithelial cell lining of renal tubules, particularly in the proximal tubules.

Bajpai et al. (2012) found that on exposure to fluoride, primary and secondary lammelar epithelium become swelled and clubbing on the tip of secondary lamellae of gills, shortening, and fusion of secondary lamellae, hyperplasia and hypertrophy in chloride cells of gills. Kahirsagar et al. (2011) and Shingadia and Agharia (2013) observed the fluoride induced histopathological alteration in ovary and testis of freshwater fish Rita rita. Shingadia (2014) observed the loss of structural integrity of mucosal folds, degeneration of mucosal epithelium, vacuolation and decrease in number and rupture of goblet cells. The flask shaped goblet cells became spherical with decrease in their number \& ruptured epithelial cell lining. Columnar cells of villi formed homogenous mass due necrosis of intestinal tissue. Serosa of intestine was also ruptured. Thinness of circular muscle increased causing obliteration of sub-mucosa, which showed disruption with atrophy. Yadav et al. (2014) conducted a study to observe the alterations on fluoride exposure and its results showed that fluoride caused vacuolization, pyknotic nuclei, disruption and rupture as well as hypertrophy and hyperplasia of hepatocyte in Hetropneustes fossilis.

\subsection{Effect on Genobiotics}

National Cancer Institute Toxicological Program categorizes fluoride to be a suspicious carcinogen. On the basis of studies done, it was suggested that fluoride is one of the most damaging environmental pollutant and is deliberated as mutagenic agent, genotoxic and neurotoxic. It may induce mutagenic, genotoxic and neurotoxic effects in aquatic organisms (Bhatnagar and Regar, 2005; Azmat et al., 2007; Tripathi et al., 2009).

\section{REMEDIAL MEASURES}

Chronic fluoride intake in absence/non-availability of pure drinking water is the prime cause of fluorosis. Long term intake of fluoride is also known to cause physiological disturbances in carbohydrate and lipid metabolism and cause oxidative stress. There are no remedial measures for fluorosis other than using water purification techniques. Following are the reviews of role of medicinal plants in reducing/ ameliorating the oxidative stress caused due to fluoride intake.

\subsection{Defluoridation using water purification} techniques

The high fluoride levels in drinking water and its impacts on human and animal health have increased the importance of defluoridation studies (Chidambaram $\boldsymbol{e t}$ al., 2003). Defluoridation was reported by adsorption (Raichur and Basu, 2001), chemical treatment (Reardon and Wang, 2000), ion exchange (Singh et al., 1999), membrane separation (Dieye et al., 1998), electrolytic defluoridation (Mameri et al., 2001) and electro dialysis (Hichour et al., 2000) etc. Among various processes, adsorption was reported to be an effective, environmentally friendly and economical one (Mohan $\boldsymbol{e t}$ 
al., 2007). The advantages of biosorption are very well known, the contaminants in water are removed by getting concentrated onto a disposed of (Volesky, 2007). Biosorption offers advantages of high efficiency in dilute effluents and no requirements of nutrient. Recently substantial interest was seen on the biosorbent material's applications for the removal of various pollutants and it also provides a cost-effective solution for the water management (Volesky and Holan, 1995). "Adsorption is a mass transfer process in which a constituent in the liquid or gas phase is accumulated on solid or liquid phase and separated from its original environment" (Crittenden $\boldsymbol{e t}$ al., 2005). The adsorption process has more advantages than other methods to remove pollutants from the water and wastewater, as it is having more simplified design of adsorption unit, negligible amount of sludge production and low investment costs (Malakootian et al., 2008). The uptake of anions has become a growing concern in the field of biosorption (Kratochvil and Volesky, 1998). Investigators reported various types of adsorbents namely activated alumina (Ghorai and Pant, 2004), tita-niumrich bauxite (Das et al., 2005), synthetic resins (Meenakshi and Vishwanathan, 2006), manganese oxide-coated alumina (Maliyekkal et al., 2006), carbon nanotubes (Li et al., 2003), fish bone charcoal (Killedar and Bhargave, 1993).

Mariappan et al. (2003) studied defluoridation technique using poly aluminum hydroxy sulphate (PAHS). The results of the study showed that the floc formation and settling are quick and volume of resulting sludge is very less. Sanjaykumar (2002) used various indigenous chemicals and minerals to study the defluoridation methods. The study concluded that alum can be used as an effective defluoridation agent if alum dose, alkalinity of water, water $\mathrm{pH}$ and colloidal concentration are optimized. Muthuganesh et al., (2003) used poly aluminum chloride (PAC) to study fluoride removal techniques and compared it with the most commonly existing 'Nalgonda technique'. The results from the study indicated that PAC can be an effective coagulant for fluoride removal with higher removal efficiency of about $65 \%-75 \%$ with less detention time. Bhargava and Killedar (2006) used fishbone charcoal prepared from fishbone in coastal areas and condluded that the removal of fluoride was found to be function of contact time, $\mathrm{pH}$, initial fluoride ion concentration and adsorbent (fishbone charcoal) dose. Ganguly (2006) used boiler bottom ash as an adsorbent material to separate fluoride content from the water.

7.2 Therapeutic effects of medicinal plants in reducing fluoride toxicity in water

Fluoride is toxic to all the system and cause oxidative stress in various tissues. All over the world, research is going on different plant species to study their principles and potential. Plant-based dietary therapies are considered to have higher potential for therapeutic applications as there can be minimum or no side effects with their use. Research in the area of nutrition is now being mainly focused on formulating 'healing diets' which can improve the overall health efficiently. There are various plants and plant based products having higher efficacy in reducing the oxidative stress due to fluoride, as fluorosis is considered as both endemic and global spanning in several continents. Medicinal plants play important role in amelioration of fluoride toxicity. Nutritional interventions like high intake of vitamin $C$, vitamin $D$ and calcium helps to reduce the problem of fluorosis. Emblica officinalis (G), Mangifera indica (L), Limonia acidissima (L), Averrhoa carambola (L) and leaves of Tamarindus indicus are effective to used against the fluoride toxicity The fruits and leaves of these plants are well known for their medicinal use as it contained phytosterols, saponins, polyphenols, flavonoids, ascorbic acid and fibers (Narasimhacharya and Vasant, 2012).

Murugan and Subramanyam (2002) studied the use of Aloe Vera (Indian aloe) a medicinal plant and concluded that at neutral $\mathrm{pH}$ the defluoridation was maximum. Prabavathi (2003) studied defluoridation techniques by using lignite rice husk and rice husk powder as adsorbent by varying $\mathrm{pH}$, concentration of fluoride, weight of adsorbent and contact time. Jamode et al. (2004) used fresh leaves chosen based on their crude fiber content and tress were obtained from Pipal (Ficus religliusa), neem (Azadirachta indica) and khair (Acacia catechu Willd) for the uptake of fluoride ion from the fluoridated water. During the study by using adsorption method, it was found that various parameters such as contact time, $\mathrm{pH}$, adsorbent dose, size and type of adsorbents and initial fluoride ion concentrations affect the fluoride removal efficiency at optimum conditions. Gopal and Elango (2007) used activated carbon developed from leaves of Agave sisalana by batch process. Maximum adsorption of fluoride ion was observed in the $\mathrm{pH}$ level of 6.76, optimum dosage of $5 \mathrm{~g} / \mathrm{l}$ and optimum contact time was observed to be 40 minutes. Up to $86 \%$ level, the defluoridation can be achieved using this process.

Biological materials such as leaves of neem (Azadirachta indica), peepal (Ficus religiosa) and khair (Acacia catechu) and tamarind gel and seeds have been used to defluoridate water. Various herbal or natural products are being increasingly investigated for their role in minimising the effects of fluoride toxicity for e.g., supplementation of tamarind fruit pulp increased urinary excretion of fluoride while decreasing the retention of fluoride in bone. The bark and seed extracts of Moringa oleifera and Terminalia arjuna have also been shown to 
decrease the fluoride induced toxicity. Additionally, plant metabolites such as a $43 \mathrm{kD}$ protein isolated from Cajanus indicus, quercetin and curcumin have been shown to ameliorate the fluoride induced oxidative stress and also improve the functions of kidney, liver and erythrocytes. Additionally, administration of black berry juice and black tea were found to be useful in reducing the effects of fluoride (Narasimhacharya and Vasant, 2012). Pandey et al. (2012) used biomass of Tinospora cordifolia for the sequestration of fluoride from drinking water. Ramanjaneyulu et al. (2013) used tamarind shell and papal leaf powder to remove fluoride from the drinking water. The effect of controlling parameters of adsorption like dose and $\mathrm{pH}$ of adsorbent, contact time and initial sorbate concentration for fluoride removal efficiency was studied and also found the optimum values for maximum uptake. At $\mathrm{pH}$ 2, tamarind fruit shell and papal leaf powder exhibited highest fluorine removal efficiency about $85 \%$ and $79 \%$ respectively. The medicinal plants like Amla (Emblica officinalis), lemon (Citrus lemon) and Tomato (Lycopersicon esculentum) are good source of antioxidants and played an important role in ameliorating the harmful effects of fluoride water (Sharma et al., 2014).

\subsection{Role of Vitamin C in ameliorating fluoride toxicity}

Vitamin $\mathrm{C}$ can be used as an effective fluoride ameliorating agentt as it is an excellent source of electrons, therefore, it forms free radicals by donating electron and then it can quench the fluoride ion reactivity and mitigate the harmful effects of fluoride water by increasing its urinary excretion and decreasing its retention in the body.

Shanmugam and Reddy $(\mathbf{2 0 1 5}, \mathbf{2 0 1 6})$ evaluated the protective ef toxicity in fishes and the results showed that $\mathrm{Hb}, \mathrm{RBC}, \mathrm{PCV}, \mathrm{I}$ intoxicated fishes where as WBC level was increased. Howeve returning back all the haematological parameters near to normal lev ingestion can causes a lot of severe problems to all the living organisms not only the aquatic organisms (including both plants and animals) but also the terrestrial organisms, birds as well as human beings who are using this fluoride contaminated water for drinking purpose. Fluoride toxicity causes fluorosis of various types such as skeletal, dental and non-skeletal fluorosis. To prevent this toxicity, best method is "water defluoridation" but most of the defluoridation techniques are expensive and not within reach of millions of people across the globe. So we can use focus on using various plants and plant products to ameliorate the effect of fluoride, as the medicinal plants are easily available or one can grow it in nearby areas which is available for plantation.

\section{FUTURE PERSPECTIVE}

Further research is required to discover some cost effective and eco-friendly methods of defluoridation. So that such methods can reach up to common people. Various plants are known to have therapeutic effect in fluoride toxicity but many more are yet to discover. There is need to understand the molecular mechanisms of plant and plant products in reversing the adverse effects of fluoride intoxicated tissues which will help in understanding their beneficial effects in a better way and also bridging the gap between the existing researches.

\section{REFERENCES}

[1] Agarwal, V., Vaish, A. K. and Vaish, P. (1977). Ground water quality: Focus on fluoride and fluorosis in Rajasthan, Curr. Sci, 739: 743- 746.

[2] Agniwanshi, S., Shedpure, M. and Jain, N. (2014). Effect of sodium fluoride on body weight gain and gonadosomatic index in freshwater catfishes. Journal of Industrial Pollution Control, 30(2): 339-343.

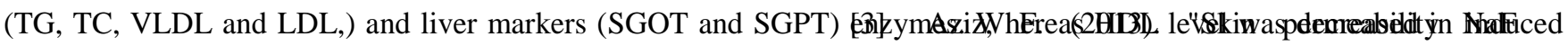

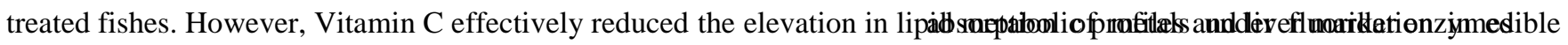
in $\mathrm{NaF}$ treated fishes.

Yadav et al., 2014 conducted an experiment to evaluated the oxidative stress biomarkers in the freshwater fish, Heteropneustes fossilis(Boch) exposed to sodium fluoride. There was increase in LPO and in response to this the antioxidant defense mechanisms were induced. The effect of chronic exposure of fluoride on LPO, enzymatic and non-enzymatic antioxidant in liver and ovary. SOD, CAT and GST levels were increased significantly while the GPx and GSH level decreased significantly and non-significantly respectively.

\section{CONCLUSION}

In many developing countries, drinking water is found to be contaminated with fluoride sources and its chronic fish.

[4] Aziz, F. R. A. and Jabeen, F. (2014). A behavioral, morphological and growth rate alterations in fresh water fish Tilapia mossambica under fluoridation, Keenjhar Lake, Thatta, Sindh, Pakistan. International Journal of Advanced Research, 376382.

[5] Azmat R. Talat R. and Ahmed K., 2007. "The Length-weight relationship, condition factor and impact of fluoride concentration in Johnius belangerii of Arabian Sea". Journal of Environmental Toxicology, 1: 138-143.

[6] Bajpai, S., Tewari, S. and Tripathi, M. (2009). "Evaluation of acute toxicity levels and behavioural responses of Hetropneustes fossilis 
(Bloch) to sodium fluoride". Aquaculture, 10(1): 37-43.

[7] Bajpai, S. and Tripathi, M. (2010). "Retardation of growth after fluoride exposure in catfish, Heteropneustis fossilis (Bloch)". Bioresources for Rural Livelihood, 67 -173.

[8] Bajpai, S., Tewari, S. and Tripathi, M. (2012). Impact of fluoride on structural changes in gills of Indian cat fish, Hetropneustes fossilis (Bloch) after acute exposure Trend. Bioscience, 4(2): 165-168.

[9] Barbier, O., Arreola-Mendoza, L. and Del Razo, L. M. (2010). Molecular mechanisms of fluoride toxicity. Chemico-Biological Interactions 188:319333.

[10] Basha, P. M., Madhusudhan, N., Rai, P., Ahmed, F. and Prasad, G. R. (2010). Effect of maternal fluoride exposure on developing CNS of rats: Protective role of Aloe vera, Curcuma longa and Ocimum sanctum. Ind J Exp Bio., 48: 830-836.

[11] Bhargava, D. S. and Killedar, D. J. (2006). Fluoride adsorption on fishbone charcoal. Journal of IAEM, 33(3): 179-183.

[12] Bhatnagar, C., Bhatnagar, M. and Regar, B. C. (2007). Fluoride-induced histopathological changes in gill, kidney, and intestine of fresh water teleost, Labeo rohita. Fluoride, 40(1): 55-61.

[13] Bhatnagar, C. and Regar, B. C. (2005). Neurodegenerative effect of Fluoride $(\mathrm{NaF})$ on the brains of fresh water teleost, Labeo rohita. Indian Journal of Environmental Sciences, 9: 15-19.

[14] Chandra, S. J., Thergaonkar, V. P. and Sharma, R. (1981). Water quality and dental fluorosis, Ind. J. Pub, 115(25): 47-51.

[15] Chidambaram, S., Ramnathan, A. L. and Vasudevan, S . (2003). "Fluoride removal studies in water using natural materials," Water $S A, 29(3)$ : 339-343.

[16] Chitra, T., Reddy, M. M. and Rao, J. V. R. (1983). "Levels of muscle and liver tissue enzymes in Channa punctatus (Bloch) exposed to NaF". Fluoride, 16:48-51.

[17] Christopher, J., Kenneth, G., Ishida, P. and Richard, M. (2004). Bold testing of drinking water treatment: Co- polymers for compatibility with polyamide reverse osmosis membranes. 9th World Filtration Congress, 18-22 April 2004, New Orleans, 1-10.

[18] Crittenden, J., Trussell, R., Hand, D., Howe, K. and Tchobanoglous, G. (2005). "Water Treatment: Principles and Design," John Wiley and Sons, New York.

[19] Das, B. K. and Mukerjee, S. C. (2003). "Effect of pyrethroid on the behavior of Heteropneustes fossilis". Comp. Biochem. Physiol. C. Toxicol. Pharmacol., 314(1): 109-112.

[20] Das, N., Pattanaik, P. and Das, R. (2005). "Defluoridation of drinking water using activated titanium-rich bauxite," Journal of Colloid and Interface Science, 292: 6-45.

[21] Dieye, A., Larchet, C., Auclair, B. and Mar-Diop, C. (1998). "Elimination des Fluorures Parla Dialyse Ionicque Croisee," European Polymer Journal, 34(1):67-75.

[22] Dousset, J. C., Rioufol, C., Philibert, C. and Bourbon, P. (1987). "Effects of inhaled HF on cholesterol, carbohydrate and tricarboxylic acid metabolism in guinea pigs". Fluoride, 20:137-141.

[23] Edmunds, W. M. and Smedley, P. L. (1996). Ground water geochemistry and health: An overview. In: Environmental geochemistry and health (Eds: J.D. Appleton, R. Fuge, G.J.H. Mc call). Special Publication 113. London: Geological Soceity. 91-105.

[24] Edmunds, W. M. and Smedley, P. L. (2003). Fluoride in natural waters occurrence, controls and health aspects. In: Medical geology. New York (Ed.: O.Selenus). Academic Press.

[25] Ellis, M. M., Westfall, B. A. and Ellis, M. D, (1948). "Determination of water quality". Fish and Wild

[26] Fujii, R. (2000). "The regulation of motile activity in fish chromatophores." Pigment Cell Res., 13(5): 300-309.

[27] Ganguly, S., Mukharjee, S. N. and Misra, A. K. (2006). Removal of Fluoride from aqueous phase using boiler bottom ash as an adsorbent. Journal of Indian Water Works Association, 47-56.

[28] Garg, R. K. and Sharma, R. (2012). "Genotoxicity assessment using micronucleus assays in Sperata

[29] Ghorai, S. and Pant, K. (2004). "Investigations on the column performance of fluoride adsorption by activated alumina in a fixed-bed," Chemical Engineering Journal, 98(1-2): 165-173.

[30] Gikunju, J. K., Githui, K. and Maitho, T. E. (1992). "Fluoride levels in bore-hole water around Nairobi".

[31] Gopal, V. and Elango, K. P. (2007). Adsorption of fluoride from aqueous solution by active carbon. Journal of Indian Water Works Association, 183191.

[32] Government of British Columbia, Ministry of Environment: Environmental Protection Division (1990) Ambient Water Quality Criteria for Fluoride: Overview report. Government of British Columbia, Victoria, British Columbia, Canada. 
[33] Guru, S. K., Rajesh, B. and Kumar, M. B. (2014). "Fluoride induced alterations in erythrocyte and related parameters of an Air breathing fish, Clarias punctatus (Bloch). Biolife, 2(4):1371-1375.

[34] Haque, S., Pal, S. and Mukherjee, A. K. (2012). Histopathological and ultra-microscopic changes induced by fluoride in soft tissue organs of the air breathing teleost, Channa punctatus (Bloch). Fluoride, 45(3 Pt 2): 263-273.

[35] Hichour, M., Persin, F., Molenat, J., Sandeaux, J. and Gavach, C. (1999). Fluoride removal from diluted solu- tions by Donnan dialysis with anionexchange membranes. Desalination, 122: 53-62.

[36] Hichour, M., Persin, F., Sandeaux, J. and Gavach, C. (2000). "Water defluoridation by donann dialysis and electro dialysis," Separation and Purification Technology, 18(1): 1-11.

[37] Hichour, M., Persin, F., Sandeaux, J. and Gavach, C. (2000). Fluoride removal from waters by Donnan dialysis. Sepa- ration and Purification Technology, 18: 1-11.

[38] Jagtap, S., Yenkie, M. K., Labhsetwar, N. and Rayalu, S. (2012). Fluoride in drinking water and defluoridation of water. Chem Rev., 112: 24542466.

[39] Jamode, A. V., Sakpal, V. S. and Jamode, V. S. (2004). Defluoridation of water using inexpensive adsorbents. Journal of Indian Institute of Science, 84: 163-171.

[40] Jha, A. N. (2004). "Genotoxicological studies in aquatic organisms: An over view. "Mutation Research/Fundamental and Molecular Mechanisms of Mutagenesis, 552(12): 1-17.

[41] Joseph, S. and Gadhia, P. K. (2000). "Sister chromatid exchange frequency and chromosome aberrations in residents of fluoride endemic regions of South Gujarat". Fluoride, 33(4):154-8.

[42] Kamble, N. A. and Velhal, V. V. 2010. "Study of sodium fluoride toxicity on hematological parameter of catfish (Clarias batrachus, Linn)". Fluoride, (1): 37-41.

[43] Kasirsagar, S. S., Kamble, S. V. and Rao, R. K. (2011). Effect of fluoride on histopathological changes in ovary of fresh water fish, Rita rita. Bionano Frontier, 4(2):276-278.

[44] Kharb, P. and Susheela, A. K. (1994). Fluoride ingestion in excess and its effect on organic and certain inorganic constituents of soft tissues. Medical Science Research, 22: 43-44.

[45] Killedar, D. J. and Bhargava, D. S. (1993). "Effects of Stirring Rate and Temperature on Fluoride Removal by Fishbone Charcoal," Indian Journal of Environmental Health, 35(2): 81-87.
[46] Kratochvil, D. and Volesky, B. (1998). "Advances in the biosorption of heavy metals," Trends in Biotechnology, 16(7): 291-300.

[47] Kumar, M. D. and Shah, T. Groundwater pollution and contamination in India: The emerging challenge. Vallabh Vidyanagar, Gujarat, India: IWMI-TATA Water Policy Research Program. $14 \mathrm{p}$.

[48] Kumar, A., Tripathi, N. and Tripathi, M. (2007). "Fluoride induced biochemical changes in fresh water cat fish ( Clarias batrachus, Linn)". Fluoride, 40(1): 37-41.

[49] Li, Y. H., Wang, S., Cao, A., Zhao, D., Zhang, X., Xu, C., Luan, Z., Ruan, D., Liang, J., Wu, D. and Wei, B. (2001). Adsorption of fluoride from water by amorphous alumina supported on carbon nanotubes. Chemical Physics Letters, 350: 412416.

[50] Li, Y. H., Wang, S., Zhang, X., Wei, J., Xu, C., Luan, Z. and $\mathrm{Wu}, \mathrm{D}$. (2003). "Adsorption of fluoride from water by aligned carbon nanotubes," Materials Research Bulletin, 38(3): 469-476.

[51] Machoy, M. A. (1995). "Fluoride magnesium interaction". Fluoride, 28:175.

[52] Madhusudhan, N., Basha, P. M., Begum, S. and Ahmed, F. (2009). Fluoride induced neuronal oxidative stress amelioration by antioxidants in developing rats. Fluoride, 42(3): 179-187.

[53] Malakootian, M., Almasi, A. and Hossaini, H. (2008). " $\mathrm{Pb}$ and Co removal from paint industries effluent using wood ash," International journal of Environmental Science and Technology, 5(2): 217222.

[54] Maliyekkal, S., Sharma, A. and Philip, L. (2006). "Manganese- oxide-coated alumina: a promising sorbent for defluoridation of water," Water Research, 40(19): 3497-3506.

[55] Mameri, N., Lounici, H., Belhocine, D., Grib, H., Prion, G. F. and Yahiat, Y. (2001). "Defluoridation of sahara water by small electro coagulation using bipolar aluminium electrodes," Separation and Purification Technology, 24(1-2): 13-119.

[56] Manna, P., Sinha, M. and Sil, P. C. (2007). “A 43 $\mathrm{kD}$ protein isolated from the herb Cajanus indicus L.

[57] Mariappan, P., Yegnaraman, V. and Vasudevan, T. (2003). Defluoridation of water using AluminaGibbsite. Indian Journal of Environmental Protection, 23(9): 975-985.

[58] McNeeley, R. N., Neimanis, V. P. and Dwyer, L. (1979). Water quality source book. A guide to water quality parameters. Inland Waters 
Directorate, Water Quality Branch, Environment, Canada.

[59] Meenakshi, S. and Viswanathan, N. (2006). "Identification of selective ion exchange resin for fluoride sorption," Journal of Colloid and Interface Science, 308(2): 438-450.

[60] Meenakshi, V. K., Garg, K., Renuka and Malik, A. (2004). Ground water quality in some villages in Haryana, India: Focus on fluoride and fluorosis, Journal Hazardous Material, 106: 85-97.

[61] Mendoza-Schulz, A., Solano-Agama, C., ArreolaMendoza, L., Reyes-M.rquez, B., Barbier, O., Del Razo, L. M. and Mendoza-Garrido, M. E. (2009). The effects of fluoride on cell migration, cell proliferation, and cell metabolism in $\mathrm{GH} 4 \mathrm{C} 1$ pituitary tumour cells, Toxicol. Lett. 190: 179-186.

[62] Murugan, M. and Subramanian, E. (2002). Application of aloe vera (Indian Aloe) - A plant material for defluoridation. Indian Journal of Environmental Protection, 22(9): 1034-1039.

[63] Muthuganesh, I., Vinodhini, V., Padmapriya, G., Sathiyanarayanan, K and Sabumon, P. C. (2003). An improved method for defluoridation. Indian $J$ Environ Health, 45(1):65-72

[64] Narasimhacharya, A. V. R. L. and Vasant, R. A. (2012). Medicinal plants as antioxidants in fluoride induced oxidative stress. Research Signpost, 267287.

[65] Narwaria, Y. S. and Saksena, D. N. (2012). "Acute toxicity bioassay and behavioural responses induced by sodium fluoride in freshwater fish Puntius sophore (Bloch)". Fluoride, 45(1): 712.

[66] Neuhold J. M. and Sigler W. F. (1960). "Effect of sodium fluoride on carp and rainbow trout". Trans Am and Molecular Biology, 40(3): 382-395.

[67] Pandey, P. K., Pandey, M. and Sharma, R. (2012). Defluoridation of water by a biomass: Tinospora cordifolia. Journal of Environmental Protection, 3: 610-616.

[68] Pendrys, D. G. and Katz, R. V. (2001). Risk factors for enamel fluorosis in optimally fluoridated children born after the US manufacturers' decision to reduce the fluoride concentration of infant formula. American Journal of Epidemiology, 148:967-974.

[69] Podder, S., Chattopadhyay, A., Bhattacharya, S. and Ray, M. R. (2008). "Differential in vivo genotoxic effects of lower and higher concentrations of fluoride in mouse bone marrow cells". Fluoride, (4): 301-307.

[70] Prabavathi, N.T., Ramachandramoorthy, R., Edison, R., Kavitha, B., Sivraj, C. and Srinivasan. (2003). Drinking water of salem district-estimation of fluoride and its defluoridation using lignite rice husk and rice husk powder. Indian journal of Environmental Protection, 23(3): 304-308.

[71] Raichur, A. M. and Basu, M. J. (2001). "Adsorption of Fluo-ride onto Mixed Rare Earth Oxides," Separation and Pu-rification Technology, 24: $121-127$

[72] Ramanjaneyulu, V., Jaipal, M., Yasovardhan, N. and Sharada, S. (2013). Kinetic studies on removal of fluoride from drinking water by using tamarind shell and pipal leaf powder. International Journal of Emerging Trends in Engineering and Development, 3(5): 146-155.

[73] Reardon, E. J. and Wang, Y. (2000). "Limestone reactor for fluoride removal from waste waters," Environmental Sci-ence \& Technology, 34(15): 3247- 3253.

[74] Rubel, J. F. (1983). The removal of excess fluoride from drinking water by the activated alumina method. In: Shupe, J.L., Peterson, H.P. and Leone, N.C. Eds., Fluoride effects on vegetation animals and humans. Paragon Press, Salt Lake City, 345349.

[75] Sahu, U., Choubey, K. and Gangadhar. (2014). Behavioral changes in Clarias Batrachus due to fluoridicated toothpaste. Shrinkhala, 2.

[76] Sanjaykumar, Gopal, K. and Seth, P. K. (2002). Indigenous minerals for defluoridation of water, Indian journal of Environmental Protection, 22(4): 361-372.

[77] Shaikh, F. I. (1999). "Chronic toxic effects of heavy metals on some physiological aspect of

[78] Shanmugam, K. R. and Reddy, S. (2016). Effect of vitamin $\mathrm{c}$ on haematobiochemical parameters in sodium fluoride $(\mathrm{NaF})$ intoxicated Channa punctatus fishes. Indo American Journal of Pharmaceutical Research.

[79] Shanmugam, K. R. and Reddy, S. A. (2015). Protective effect of vitamin $\mathrm{c}$ in sodium fluoride $(\mathrm{NaF})$ induced toxicity in fishes: a study with reference to lipid metabolic profiles and liver markers. Indian Journal of Fundamental and Applied Life Sciences.

[80] Sharma, J. D., Bhinda, S., Sharma, P. K., Kumari, M. and Boriwal, R. (2014). Therapeutic efficacy of medicinal plants to mitigate fluorosis. Journal of Global Biosciences. 3(5): 802-807.

[81] Shi X., Zhuang P., Zhang L., Feng G., Chen. L., Liu J. andWang R. (2009b). Growth inhibition of Siberian Sturgeon ( II) from dietry and waterborne fluoride. Research Report. Fluoride, 137-141. 
[82] Shi, X., Zhuang, P., Zhang, L., Feng, G., Chen, L., $\mathrm{Qu}, \quad$ L. and Wang, R. (2009a). "The bioaccumulation of

[83] Shingadia, H. U. (2014). Chronic revelation to sodium fluoride induces pathohistological alterations in intestine of Poecilia reticulata peter. Bionano frontier, 2: 293-296.

[84] Shingadia, H. U. and Agharia, E. R. (2013). "Sodium fluoride induced alteration in dehydrogenase and acetyl cholinesterase activity in vital tissues of Poecilia reticulata peters". Life Science Leaflet, 122 -128.

[85] Singh, B., Sen, P. K. and Maunder, J. (1999). "Removal of fluoride from spent pot liner leachate using ion exchange," Water Environment Research, 71(1): 36-42.

[86] Srimurali, M., Pragathi, A. and Karthikeyan, J. (1998). A study on removal of fluorides from drinking water by ad- sorption onto low-cost materials. Environmental Pollution, 99: 285-289.

[87] Susheela, A. K., Kumar, A., Betnagar, M. and Bahadur, M. (1993). Prevalence of endemic fluorosis with gastro-intestinal manifestations in people living in some north-Indian villages, Fluoride, 26: 97-104.

[88] Susheela, A. K. (2007). A treatise on fluorosis. Fluorosis Research and Rural development foundation, New Delhi, 133p.

[89] Thurberg, F. P., Cable, W. D., Dawson, N. A., Mac Innes, D. R. and Wehzleff, D. R. 1975. "Respiratory response of larval, juvenile and adult surf clams, Spisula solidissima, In; Respiration of marine organisms Life Service Research Report 9, U.S. Department of Interior, Government Printing Office, Washington, D.C., 122.

[90] Tripathi N., Bajpai S., and Tripathi M. (2009). "Genotoxic alterations induced by Fluoride in Asian catfish,Clarias batrachus (Linn.)". Fluoride, 42(4): 292-296.

[91] Tripathi, A., Tripathi, N., Kumar, A. and Tripathi, M. (2006). Effect of fluoride on vertebral coloumn of a fresh water fish Channa punctatus. J.Appl. Biosci., 32(2): $164-167$.

[92] Tripathi, M., Tripathi A. and Gopal, K. (2005). "Impact of fluoride on pigmentation of a freshwater fish" Channa punctatus. .J.Appl. Biosci., 31(1): 35-38.

[93] Valdez, L., Fregozo, C. S., Beltran, M. L., Coronado, O. G. and Vega, M. I. (2011). Effects of the fluoride on the central nervous system. Neurologia, 26(5): 297-300.

[94] Varadajan, N. and Purandara, B. K. (2008). Fluoride contamination in ground water of malaprabha sub basin, Journal of environ science and engg., 50(2): 121-126.

[95] Varier, P. S. (1996). Indian medicinal plants: A compendium of 500 species, Vol. 1-5. Orient Longman Ltd., Madras.

[96] Venkata Mohan, S., Ramanaiah, S., Rajkumar, B. and Sarma, P. (2007). "Biosorption of fluoride from aqueous phase onto algal spirogyra io1 and evaluation of adsorption kinetics," Bioresource Technology, 98(5): 1006-1016.

[97] Venkata, M. S., Nikhila, P. and Reddy, S. J. (1995). Determination of fluoride content in drinking water and development of a model in relation to some water quality parameters, Fresenius Envir Bull, 4, 297-302.

[98] Verma, A., Solanki, M. S. and Shrivastava, S. 2015. Behavioral changes in Catla catla due to fluoridated toothpaste. Indian streams research journal, 5 (7).

[99] Volesky, B. (2007). "Biosorption and Me," Water Research, 41(18): 4017-4029.

[100] Volesky, B. and Holan, Z. R. (1995). "Biosorption of heavy metals," Biotechnology Progress, 11(3): 235-250.

[101] Wang, Y. and Reardon, E. J. (2001). Activation and regen- eration of a soil sorbent for defluoridation of drinking water. Applied Geochemistry, 16: 531-539.

[102] Wang, A., Xia, T., Ru, R., Yuan, J., Chen, X. and Yang, K. (2004). Antagonistic effect of selenium on oxidative stress, DNA damage, and apoptosis induced by fluoride in human hepatocytes. Fluoride, 37: 107-116.

[103] Wedepohl, K. H. (1974). Hand book of geochemistry. Springerverlage berlin. (Ed.: Heidelberf). New York. 2: 9.

[104] Yadav, S. S., Kumar, R. and Tripathi, M. (2014). Effects of fluoride exposure on some enzymatic and histopathological changes in the liver of Heteropneustes fossilis (Bloch). International Journal of Fauna and Biological Studies, 1(5):8084.

[105] Yang, M., Hashimoto, T., Hoshi, N. and Myoga, H. (1999). Fluoride removal in a fixed bed packed with granular cal- cite. Water Research, 33: 33953402.

[106] Yilmaz, M., Gul, A. and Erbasli, K. (2004). "Influence of water hardness on cadmium toxicity to Salmogairdneri (Rush)". Bull. Environ. Contam.Toxicol.,56 (4): 575-582. 